\title{
Manifestations of the human T-cell Iymphotropic virus type I infection in childhood and adolescence
}

\author{
Achiléa Lisboa Bittencourt¹, Janeusa Primo², Maria de Fátima Paim de Oliveira ${ }^{3}$
}

\begin{abstract}
Objectives: To review the literature on diseases linked with infection by human T-cell lymphotropic virus type I (HTLV-I) in childhood and adolescence, with focus on clinical aspects, diagnosis, pathogenesis, progression and treatment.

Sources: Medical literature published during the last 20 years identified using PubMed and MEDLINE and from specialized medical books, with emphasis on infective dermatitis associated with HTLV-I (IDH), on the juvenile form of HTLV-associated myelopathy/tropical spastic paraparesis (HAM/TSP), on adult T-cell leukemia/lymphoma (ATL) and on HTLV-I-associated uveitis. Keywords used to search databases were: HTLV-I-associated infective dermatitis, HTLV-Iassociated myelopathy/tropical spastic paraparesis, adult T-cell leukemia/lymphoma, HTLV-I-associated uveitis.

Summary of the findings: IDH is a chronic, relapsing and infected dermatitis of childhood which always involves the scalp and which may progress to HAM/TSP and ATL. HAM/TSP is a chronic and incapacitating myelopathy of adults. There are 17 well-documented cases of HAM/TSP in children and adolescents in the literature, 12 of whom are patients with IDH. In contrast with the adult form of the disease, the juvenile form is rapid and progressive. ATL is a type of Tcell leukemia/lymphoma that affects adults and is generally fatal. Eleven of the 24 published reports of ATL in children and adolescents were diagnosed in Brazil.

Conclusions: These diseases are likely to be more common in childhood and adolescence than the literature would suggest. It is advisable that serological testing be performed for HTLV-I in children and adolescents suffering from chronic and relapsing eczema, with signs and symptoms of myelopathy or with a diagnosis of T-cell leukemia/lymphoma. It is important that pediatricians know how to recognize the pediatric manifestations of this infection in order to correctly diagnose them and offer their patients appropriate guidance and treatment.
\end{abstract}

J Pediatr (Rio J). 2006;82(6):411-20: HTLV-I infection in childhood and adolescence, vertical transmission of HTLVI, HTLV-I-associated infective dermatitis, HAM/TSP in childhood and adolescence, ATL in childhood and adolescence.

\section{The human T-cell lymphotropic virus type I (HTLV-I)}

The human T-cell lymphotropic virus type I (HTLV-I) is a retrovirus that was first isolated in 1980 from T-cells of a patient with cutaneous lymphoma, and was soon after linked to a type of lymphoma that had been

1. Doutora. Professora de Patologia, Faculdade de Medicina, Universidade Federal da Bahia (UFBA), Salvador, BA, Brasil. Pesquisadora nível 1A, Conselho Nacional de Pesquisa (CNPq). Líder, Grupo de Pesquisa sobre Manifestações Infanto-Juvenis da Infecção pelo HTLV-I na Bahia, Diretório dos Grupos de Pesquisa no Brasil do CNPq.

2. Mestre. Neuropediatra, Hospital Universitário Professor Edgard Santos (HUPES), UFBA, Salvador, BA, Brasil.

3. Mestre. Dermatologista, HUPES, UFBA, Salvador, BA, Brasil.

Manuscript received Jun 30 2006, accepted for publication Aug 162006

Suggested citation: Bittencourt AL, Primo J, de Oliveira MF. Manifestations of the human T-cell lymphotropic virus type I infection in childhood and adolescence. J Pediatr (Rio J). 2006;82:411-20. previously described in Japan, the adult T-cell leukemia/ Iymphoma (ATL). ${ }^{1}$ Soon after the discovery of HTLV-I, HTLV-II was identified in cells from a patient with hairy cell leukemia. The two viruses are similar in $66 \%$ of their genome sequences and, because of this, there are cross reactions between them. Both are retrovirus that infect mainly the helper T lymphocytes. So far, HTLV-II has not been consistently linked with any given pathology; however, there are publications that have related it to neurological diseases. 2,3

The action of the HTLV-I within the organism is very slow, and the majority of the diseases it causes are considered to be of late onset, emerging in adulthood. ${ }^{2}$ It is important to point out that more than $90 \%$ of the HTLV-I carriers remain asymptomatic. ${ }^{3}$ 


\section{Frequency of infection by HTLV-I}

Infection by HTLV-I is endemic in many parts of the world, including the southwestern Japan, Caribbean islands, Central and Western Africa, the southeastern United States and South America. ${ }^{1}$ In Salvador, Brazil, a frequency of $1.35 \%$ was observed among blood donors, whereas, in other Brazilian state capitals (Recife, Rio de Janeiro, Manaus and Florianópolis) infection rates varied from 0.3 to $0.8 \% .^{4}$ Nevertheless, a higher frequency has been recorded in Pará (1.6\%). ${ }^{3}$ In Campo Grande (MS), an infection rate of $10 \%$ was observed among Japanese immigrants and their descents, and, in Salvador (BA), a rate of $25 \%$ was observed among injecting drug users. ${ }^{2}$ The overall prevalence of this infection in the general population of Salvador was estimated to be $1.76 \% .^{5}$

An HTLV-I infection frequency of $1.1 \%$ was observed among pregnant women in Belo Horizonte (MG) and of $0.84 \%$ in Salvador (BA). ${ }^{3,6}$ An epidemiological survey of the infected pregnant women in Salvador suggested that their infections had primarily been acquired via breastfeeding and, in second place, sexually. In these women the infection did not interfere with the course of pregnancy, and $15.6 \%$ of them reported having had eczema when children, whereas, just $0.85 \%$ of a control group of HTLV-I-negative pregnant women had had eczema. This demonstrates that there is a close relationship, in Salvador, between childhood eczema and infection by HTLV-I. ${ }^{6}$

\section{Modes of transmission}

Transmission of HTLV-I is by sexual contact, blood transfusion, vertical (from mother to child) or, in injecting drug users, through sharing contaminated needles. ${ }^{2}$ Sexual transmission is primarily from men to women, at a rate of around $61 \%$, whereas transmission from women to men is uncommon, at around $0.4 \%$.

The principal form of vertical transmission is via breastfeeding. Transmission via human milk is almost always vertical, but it may occur by means of breastfeeding by wet-nurses or cross-breastfeeding (horizontal transmission). ${ }^{2}$ The milk of mothers who are seropositive for HTLV-I contains infected cells and experimental infection has been achieved administering this milk orally to marmosets. ${ }^{7-9}$ In areas where HTLV-I is endemic, from 7 to $42 \%$ of breastfed children acquire the infection. ${ }^{10-15}$ It is also known that non-breastfed infants can also acquire the infection vertically, with a frequency that varies from 3.3 to $13.8 \% .{ }^{10-15}$ In these cases, transmission is likely to be transplacental or from contamination in the birth canal. Bittencourt et al., in 2002,16 used polymerase chain reaction ( $P C R$ ) to assess 41 children who were born to carriers and who had not been breastfed (mean age of 11 months) and did not detect any cases of transmission.
However, $81 \%$ of these mothers had undergone elective caesarian. This type of delivery reduces vertical infection rates of the acquired immunodeficiency virus (HIV) infection, and the possibility that it may also have interfered in the absence of vertical transmission in these cases cannot be ruled out. 16

\section{Diagnosis of infection}

Routine diagnosis of HTLV-I infection is serological, by means of serum assay for anti-HTLVI/II antibodies, the enzyme-linked immunosorbent assay (ELISA) being the most widely used. Diagnosis must be confirmed using western blot technique, which allows differentiation between the types I and II of the HTLV. ${ }^{6}$ It should be pointed out that a positive test before 1 year of age may not represent infection and may be merely the result of maternal antibodies passing through the placenta. ${ }^{2}$

In cases that cannot be confirmed using the western blot technique, molecular testing should be carried out, the PCR being the most often used. Detection by PCR does not depend on antibody production because it directly detects the proviral DNA. As a result of its elevated sensitivity and specificity, this method is capable of shedding light on indeterminate serological status and even of detecting infections in seronegative individuals with clinical status suggestive of HTLV-I-associated diseases. This is also the method of choice for very early investigation of infection. ${ }^{2}$

\section{The principal diseases related to HTLV-I}

In contrast with the majority of infected individuals who remain asymptomatic, in other patients HTLV-I can cause serious diseases, including ATL, HTLV-I-associated myelopathy/tropical spastic paraparesis (HAM/TSP) and HTLV-I-associated infective dermatitis (IDH). ${ }^{2}$ IDH is a childhood disease; however, ATL and HAM/TSP are considered to represent adult diseases, as is HTLV-Iassociated uveitis. Other diseases have been related to this virus in adulthood, such as lymphocytic T-cell alveolitis, Sjögren's syndrome, thyroiditis, Behçet's disease, arthropathy and polymyositis. ${ }^{17}$

Infection by HTLV-I involves dysregulation of the immune system with spontaneous lymphoproliferation and simultaneous cytokine production by helper T-cells types I and II, 18,19 which makes the infected individuals more susceptible to other infections and parasitoses, such as scabies and strongyloidiasis. 20-22 It was recently observed in Salvador that HTLV-I carriers have a greater risk for tuberculosis than do individuals who are not infected with the virus. ${ }^{23}$

Lack of knowledge of IDH, together with the belief that ATL, HAM/TSP and HTLV-I-associated uveitis are late- 
onset diseases, may be responsible for the low number of HTLV-I-associated diseases diagnosed during childhood and adolescence. In the pediatric literature, these pathologies are scarcely found, and we believe it is quite important to underscore their occurrence.

\section{HTLV-I-associated infective dermatitis Introduction}

IDH is a recurrent, infected form of eczema that was described in Jamaica in 1966 by Sweet, ${ }^{24}$ and which was later linked to HTLV-I. ${ }^{25}$ Onset is generally after 18 months of life and the disease rarely persists until adulthood. ${ }^{26}$ In these cases transmission is vertical. There is only one report of a case where transmission was via blood transfusion. 27 The frequency of IDH is greater among females, varying from 60 to $65.27,28$

The greatest number of cases of IDH have been reported in Jamaica 28 and, more recently, in Bahia. 27 Smaller series of cases have been described in Trinidad and Tobago, ${ }^{29}$ Peru $^{30}$ and Senegal. ${ }^{31}$ Curiously, in Japan, where the prevalence of HTLV-I infection is elevated, only two cases of children with IDH have been reported, both of which progressed to ATL in adulthood. 32

In Jamaica, IDH is responsible for $10 \%$ of childhood eczema cases. ${ }^{33}$ In that country the prevalence of HTLVI is $1 \%$ in children, and $8.1 \%$ in individuals older than 20 years. ${ }^{34}$ Maloney et al. ${ }^{35}$ monitored 28 children with HTLV-I for an average of 7.5 years, observing that only one developed IDH. Based on this observation, they concluded that the probability of developing IDH by 4 years of age was $2 \%$ among the perinatally infected children.

\section{Clinico-pathological and immunohistochemical aspects}

The lesions in IDH are erythematous, scaly, and crusted. They involve the scalp, neck, ears (Figure 1), retroauricular areas, axillae, groin, genitalia (Figure 2) and several other parts of the body. The patients complain of itching that is less intense than that found in atopic dermatitis (AD). ${ }^{27}$ Patients also exhibit erythematous, scaly, and/or crusted lesions in the nostrils and/or rhinitis and, with frequency, blepharoconjunctivitis (Figure 3). The disease may become generalized and exhibit pustules, erythematous and scaly follicular papules (Figure 1), and retroauricular fissures. IDH is always associated with infection by Staphylococcus aureus and/or Streptococcus B-hemolyticus. ${ }^{27}$

According to La Grenade et al. 28 the principal diagnostic criteria for the diagnosis of IDH are: 1 . Eczema of the scalp, axillae, groin and external ear, retroauricular regions, eyelids, paranasal skin and/or neck; 2 . Chronic rhinorrhea and/or crusted lesions at the nasal vestibule; 3. Chronic

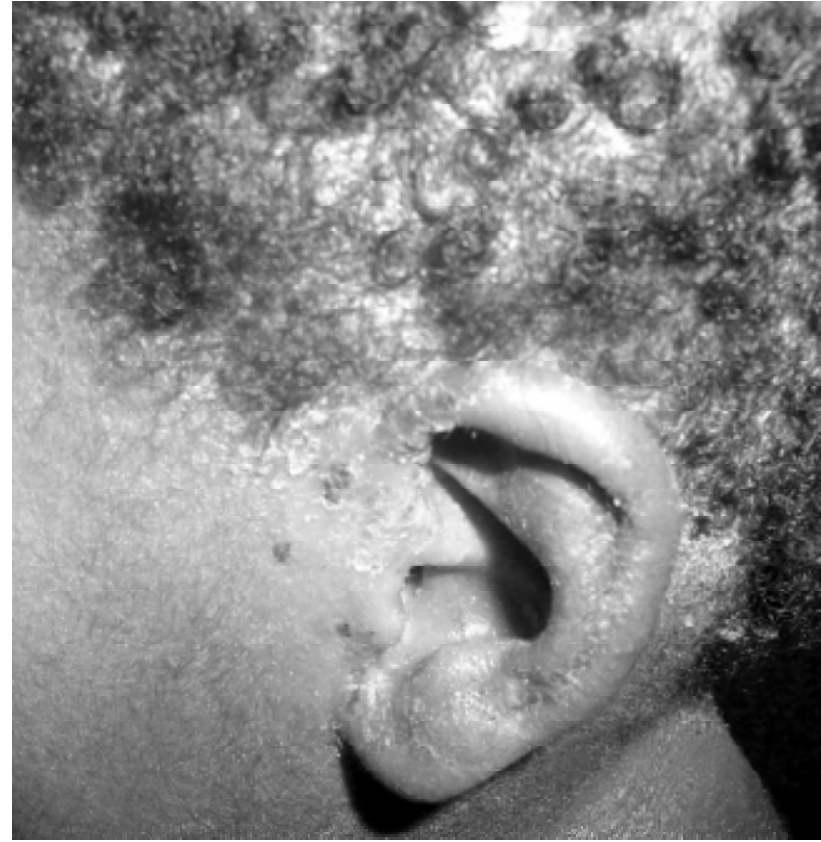

Figure 1 - Infective dermatitis with lesions in the scalp, external ear and neck

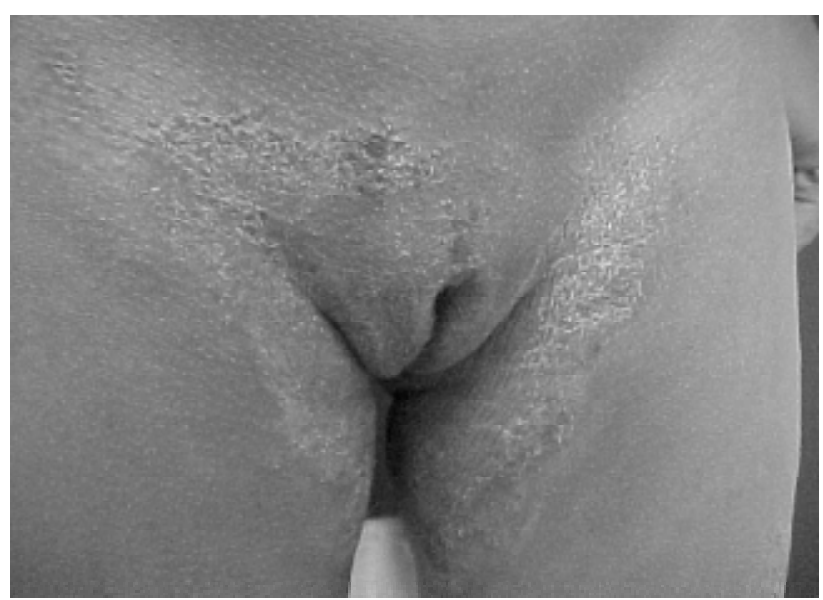

Figure 2 - Erythematous, scaly lesions with crusts in the groin and genitalia

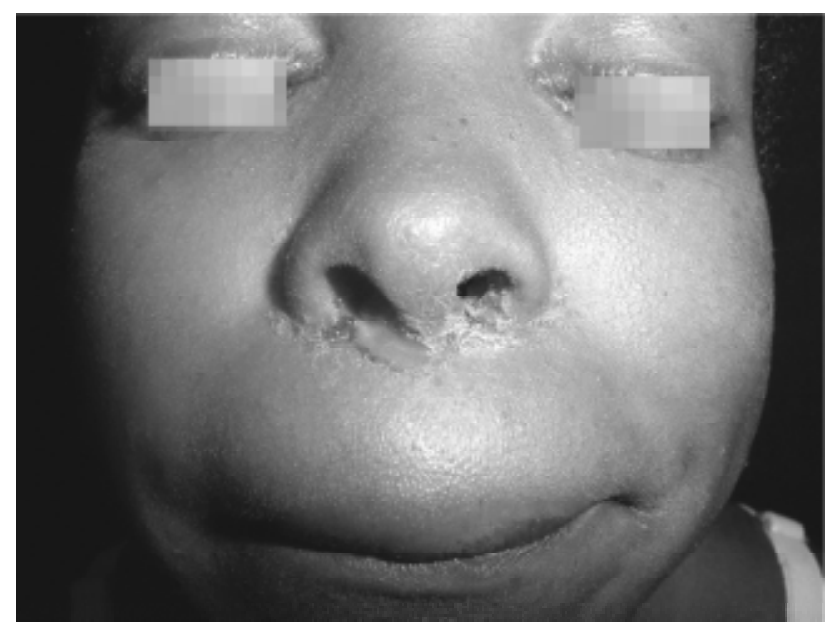

Figure 3 - Blepharoconjunctivitis and lesions in the nostrils with exulceration and crusting 
relapsing dermatitis which responds immediately to antibiotic therapy and relapses immediately once treatment is withdrawn. 4. Early childhood onset. 5. HTLV-I seropositivity. These authors state that items one, two and five must be present and that at least two of the areas listed in item one must be involved for that criterion to be met. While these criteria consider crusting of the nostrils and/or rhinitis as compulsory elements for diagnosis, these features are not persistent and may be absent in some cases. 27

In common with what is observed with adult infected by HTLV-I, ${ }^{20,22}$ complications of infectious or parasitic nature are also seen in patients with $\mathrm{IDH}$, such as otitis, pyodermatitis, scabies and strongyloidiasis. $27,31,36,37$

Although it is not possible to diagnose IDH histopathologically, histology is still important for differential diagnosis from other inflammatory dermatoses and mycosis fungoides. Histological findings of IDH are those of spongiotic dermatitis or simple chronic dermatitis. Infrequently histology may mimic psoriasis or mycosis fungoides. 38

In IDH, the inflammatory infiltrate is predominantly made up of $\mathrm{CD} 8+\mathrm{T}$-cells. In contrast with what is observed in AD and in seborrhoeic dermatitis (SD), CD8+ lymphocytes predominate over CD4+ Iymphocytes. Nevertheless, the CD8+ lymphocytes are perforin negative and, rarely, granzyme- $\mathrm{B}+$, indicating that they are not activated cytotoxic T-lymphocytes. In contrast, in $A D$, lymphocytes are perforin+ and granzyme-B+ and do appear to contribute to the inflammatory process. 38

\section{Differential clinical diagnosis}

In IDH differential diagnosis should primarily aim to rule out $A D$ and later, when the child enters puberty, SD. A positive serological test for HTLV-I is not the unique criterion to diagnose IDH in patients with chronic eczema in endemic areas, because cases of AD or SD may be seropositive in these areas.

The lesions observed in the childhood form of $A D$, which begin after 2 years of age, are similar to a certain extent to those observed in IDH; however, IDH lesions are more infected and exuberant. On the other hand, itching caused by IDH is less intense than that found in $A D$. Besides, in contrast to $A D$, in IDH crusting of the nasal vestibule, fissures, generalized rash with very small papules and blepharoconjunctivitis are observed. 39,40 Childhood SD is considered as a rare entity, however Maloney et al. ${ }^{41}$ observed that $25 \%$ of children carrying HTLV-I had SD. The lesions in $\mathrm{IDH}$, in contrast to the lesions found in SD, are more exsudative and fetid with yellowish crusts. In addition, the SD lesions present greasy scales. ${ }^{42}$ On the other hand, the Pityrosporum yeasts, which frequently occur in SD, 43 are not observed in IDH lesions. Furthermore,
IDH responds well to sulfamethoxazole/trimethoprim and to antibiotics, which is not a characteristic of SD. ${ }^{27}$

\section{Pathogenesis}

It is not known why only a few infected children developed IDH and the majority remain asymptomatic. It is possible that genetic factors in the host play an important role in the genesis of IDH. La Grenade et al. ${ }^{44}$ used human leukocyte antigen (HLA) genotyping to study three generations of one same family containing nine carriers and three cases of IDH, of whom a mother and one child later progressed to HAM/TSP. They observed that the mother and the child with IDH and one other child who was a carrier had a class II DRB1*DQB1* haplotype, which is the same that has been described among Japanese patients with HAM/TSP.

Some research has shown that patients with IDH have a higher viral load. According to La Grenade et al. ${ }^{28}$ patients with AD who are infected by HTLV-I present lower serum anti-HTLV-I antibodies than patients with IDH. Considering that there is a positive correlation between the levels of anti-HTLV-I antibodies and the viral load, 41,45 this finding appears to indicate that the viral load of IDH patients is more elevated than that of children who are only carriers. Recently, Maloney et al. ${ }^{35}$ studying 28 infected children, observed that just two of them exhibited elevated viral load, and one of these developed IDH.

The marked cutaneous inflammatory involvement may be the result of cytokine action. It is known that the Tax viral protein can transactivate genes of several proinflammatory cytokines, including interleukin-1, interleukin- 6 and tumor necrosis factor alpha (TNF- $\alpha$ ). It is possible that these cytokines could amplify and maintain the cutaneous inflammatory reaction, which would also explain the recurrent nature of IDH. ${ }^{46} \mathrm{~A}$ study of the cytokine profile in IDH, evaluating the concentrations of IFN- $\gamma$ and TNF- $\alpha$ in the supernatant of the peripheral blood mononuclear cells, demonstrated high levels of these cytokines compared with infected individuals who did not have IDH (Nascimento, personal communication).

\section{Clinical course and treatment}

IDH may progress to HAM/TSP47 and ATL. 32,48,49 Forty-four percent of ATL cases diagnosed in Bahia have a history of severe eczema in childhood, resistant to treatment and with involvement of the scalp, undoubtedly IDH cases. 50

It is, therefore, advisable that serology for HTLV-I be carried out in all cases of severe eczema in children and adolescents. Additionally, IDH cases should be monitored with periodic clinical and neurological examinations. Since strongyloidiasis is a predisposing cofactor for a progression 
to $A T L$, leading to clonal expansion of lymphocytes, and considering that this parasitosis is frequently asymptomatic, it is important that it be searched routinely in all patients with $\mathrm{IDH}$, since appropriate treatment can reverse clonal expansion. 51

Since IDH is always associated with bacterial infection, it responds well to antibiotic therapy and oral trimethoprim/ sulfamethoxazole. Nevertheless, when medication is withdrawn relapse occurs. 27

\section{HAM/TSP in childhood and adolescence Introduction}

HAM/TSP is a severe and incapacitating myelopathy, more common among females and with a mean age of onset of $46.52,53$ It is generally considered to be the result of an infection acquired during adulthood through blood transfusion or sexual transmission. 54

According to the guidelines of the World Health Organization (WHO), clinical manifestations and the presence of anti-HTLV-I antibodies in serum and cerebrospinal fluid are considered essential criteria for the diagnosis of HAM/TSP. ${ }^{47}$ Clinical status is compatible with chronic and progressive spastic paraparesis, primarily involving the pyramidal tract (lower limb hyperreflexia, clonus and Babinski reflex), with proximal weakness of lower limbs, neurogenic bladder and lumbago. 47

During the evolution of HAM/TSP, invariably motor and/or sensory signs and symptoms related to symmetrical limited crural function are observed. These include fatigue when walking, resulting from progressive spasticity of the lower limbs, hyperreflexia, clonus, muscle weakness, and sensory complaints, such as lumbar pain, cramps, numbness and/or tingling with tactile dysesthesia of the feet. 47,53 These signs and symptoms are present with different intensities throughout the several clinical phases of the disease.

In the differential diagnosis, it is important to rule out other infectious diseases which can compromise the spinal cord, such as syphilis, toxoplasmosis, cysticercosis and schistosomiasis, by testing for antibodies in cerebrospinal fluid and culturing for other microorganisms, including Mycobacterium tuberculosis. 47

Depending on disease duration and on the number of cells present in the cerebrospinal fluid (CSF), HAM/TSP cases are classified as acute, subacute or chronic. ${ }^{53}$ When evaluating progress, it is important to apply Osame's motor incapacity scales and the Kurtzke expanded scales, with the aim of measuring the degree of incapacity of the various functional systems, in addition to controlling progression and the response to different treatment attempts. 47

Although HAM/TSP is considered a pathology of adults, there are 17 well-documented cases in the literature of
HAM/TSP diagnosed in children and adolescents, 13 of which were described in Brazil. 47,49,55-61 In these cases a predominance of the female sex was observed. In contrast with the adult form of the disease, in the juvenile form of HAM/TSP infection is acquired vertically. 47,62

\section{Clinical status, diagnosis and progression}

The great majority of cases of HAM/TSP in children and adolescents occurred in patients with IDH or who have had IDH. ${ }^{63}$ In a study that carried out neurological assessment of 20 IDH patients in Salvador, it was observed that only eight patients $(40 \%)$ exhibited no neurological manifestations. In six cases (30\%), a conclusive diagnosis of HAM/TSP was made; four patients (20\%) manifested fluctuating myelopathy symptoms; 63 and one of them received the same diagnosis later (Primo, unpublished data). Furthermore, two other cases (10\%) exhibited clinical manifestations suggestive of peripheral neuropathy. ${ }^{63}$ This pathology has been described in adults with asymptomatic infection or with HAM/TSP. 64

Vesical dysfunction, characterized by difficulty in emptying the bladder, urinary urgency and incontinence, that is observed in adult HAM/TSP 65,66 are also found in the juvenile form of the disease. 47 Considering that bladder involvement may go unnoticed, urodynamic studies are important for diagnosis, and are also useful for treatment and follow-up of vesical dysfunction. Urodynamic studies carried out for three juvenile cases of HAM/TSP revealed similar features to those observed in adults. 67

There are reports of short stature, hypocalcemia, and small increases in urinary phosphorus excretion and of cyclic adenosine monophosphate (AMP) after injection of parathyroid hormone (HPT) in juvenile HAM/TSP, findings which led to the diagnosis of pseudohypoparathyroidism (PHP). ${ }^{68}$ According to Machigashira et al., ${ }^{69}$ HTLV-I infection does not induce PHP, but PHP may be a risk factor for the development of HAM/TSP in carriers of the virus. This aspect should be investigated more extensively.

Although the juvenile form of HAM/TSP exhibits similar clinical manifestations to the adult form, its clinical course is different, being rapidly progressive. 47,58

\section{Pathogenesis}

Recently, a clustering of HAM/TSP cases was observed in three families, between siblings or between mother and child, ${ }^{47}$ which suggests that genetic factors are involved in the genesis of this pathology. In Japan, it was observed that adult HAM/TSP had a different immunogenetic background from ATL. 70

Patients with IDH and HAM/TSP exhibit high levels of anti-HTLV-I antibodies. ${ }^{47}$ Considering that there is a correlation between the levels of antibodies and the 
proviral load, 41,45 it is highly probable that these patients have an elevated viral load, which could be responsible for the early onset of HAM/TSP.

Studies of HAM/TSP in adults have shown that there is a great increase in the relative risk for development of adult HAM/TSP when the proviral load exceeds one copy per 100 mononuclear cells in peripheral blood. ${ }^{71}$ It is known that the presence of the HLA-A*02 gene in adult Japanese patients is associated with a significant reduction in the viral load and in the risk for HAM/TSP. ${ }^{72}$ In contrast, HLA-DRB1*0101 is associated with an increased risk for HAM/TSP. 70

\section{Treatment}

As an immune-mediated pathology, HAM/TSP has been treated like other immunological diseases of the nervous system. Studies indicate that, in some patients, clinical improvement is accompanied by reduction in the antibody titers and cell counts in CSF. Intravenous administration of methylprednisolone during 3-5 days, followed by oral prednisone ( $1 \mathrm{mg} / \mathrm{kg} /$ day) during 3 months, is indicated in cases of acute or subacute progression associated with rapid functional deterioration and inflammatory pattern of CSF.47,58 Other treatment alternatives, such as alpha-interferon, gammaglobulin, vitamin C, pentoxifylline and danazol, are also being used. ${ }^{63}$ Symptomatic treatment is also indicated with myorelaxants and anticonvulsants (baclofen and oxcarbazepine) to relieve spasticity and neuropathic pain. As these patients are highly compromised by psychological and motor aspects and less social inclusion, they demand the care of a multidisciplinary team (physician, psychologist, physiotherapist, occupational therapist, nurse and teacher).

Serological screening for HTLV-I must be performed in children and adolescents with mielopathy in endemic areas, not only to define the presence of HAM/TSP, but also to provide an early and appropriate treatment and a better quality of life.

\section{Adult T-cell leukemia/lymphoma \\ Introduction}

ATL is a severe and generally fatal form of leukemia/ lymphoma that is etiologically linked with HTLV-I. Notwithstanding the fact that ATL is generally related to vertical transmission, ${ }^{61}$ the latent period before its development is very long. ${ }^{73}$ In Brazil, many cases of ATL have been detected, the mean age varying from 42 to 49 years, which is a decade younger than in ATL cases in Japan. 1,74

As has already been mentioned, it has been observed that Strongyloides stercoralis stimulates oligoclonal proliferation of cells infected with HTLV-I in asymptomatic carriers, suggesting that this infestation may be a cofactor for the development of ATL. ${ }^{75}$ It is probable that the earlier onset of ATL in developing countries where the prevalence of Strongyloides stercoralis infestation is higher, is at least in part the result of a greater exposure of HTLV-I carriers to this parasite.

There are 24 published reports of ATL diagnosed in childhood or adolescence (Table 1). ${ }^{76}$ The clinical manifestations of these cases are, in the majority, similar to those observed in adults. Six cases were younger than 11 years of age at the time of diagnosis. $31,77-91$

Maternal serology was positive in 16 of the 19 cases of the literature where this information was available, indicating vertical transmission of HTLV-I.76 Notwithstanding, serology was negative in three mothers. In one child, transmission occurred via blood transfusion. The other two children had been breastfed by another woman, whose serological status was unknown. 88,90

\section{Clinical aspects}

ATL is classified according to clinical and laboratory data, into smoldering, acute, chronic and lymphoma. 92 The majority of the cases reported in the literature do not mention the clinical form; however, considering the clinical and laboratory data, the majority were in the acute form of ATL. Two cases were considered as chronic 31,89 and three as smoldering, ${ }^{77,89,91}$ while two others exhibited the characteristics of this last clinical form. ${ }^{79,88}$ The organs most often involved were skin, lymph nodes, liver and spleen. Bone marrow was infiltrated in 10 of the 16 cases that made this examination. Macular rash, papules, infiltrated plaques, nodules, tumors or erythroderma were described in the skin, ${ }^{76}$ not differing from what is observed in adults. ${ }^{93}$ In three cases there was an association with IDH, $31,89,91$ and in another, history was highly suggestive of this dermatosis. 86

\section{Diagnosis}

The diagnosis of the patients was hematological and/ or histopathological. In eight cases, monoclonal HTLV-I integration was observed 90 (Weyenberg \& Farré, unpublished data).

In only few cases of the literature the lymphomas were classified according to the histological type. They found pleomorphic lymphomas (currently defined as nonspecific peripheral T-lymphomas), mycosis fungoides and anaplastic large-cell lymphomas. ${ }^{76}$ These types of lymphoma have also been described in adult ATL. ${ }^{1}$

\section{Evolution}

In the 15 cases with death, the survival was less than 6 months. In eight cases in which death was not recorded, 
survival varied from 1.3 to 14 years. Three cases were considered as smoldering form, which presents a better survival, and two had the clinicopathological characteristics of this form of ATL. ${ }^{76}$ The clinical course of case 14 was abnormal. Lesions emerged at 7 years age and, at 24 years old, the patient's lesions remain restricted to the skin, although their number and size have progressively increased, making electron radiotherapy necessary to reduce them. (Bittencourt, unpublished data).

Two univitelline twins behaved differently after infection by blood transfusion soon after birth. ${ }^{88}$ One developed ATL, with cutaneous lesions from 5 years onwards, while the other remained infected and asymptomatic at least until 13 years of age. Nevertheless, there is a report of two siblings who developed lymphoma early, one at 16 years and the other at 24 years of age. ${ }^{84}$ This report demonstrates a familial tendency in the development of ATL, which has already been observed in adult patients. ${ }^{94}$

\section{Pathogenesis}

IDH cases can progress to ATL, but the mechanisms that lead to this development have not yet been elucidated. It is probable that both genetic factors of the host and external factors are involved. On the other hand, there are many cases of ATL that have no history of IDH.

In IDH, the presence of viral antigens and bacterial superantigens may stimulate the lymphocytes and, therefore, an increased number of target cells available to be infected by HTLV-I. Along with this expansion of the infected T-cells, activation signals and growth factors would be produced for uninfected T-cells, and repeated clonal expansions of these cells would then increase the chances of the additional events required for transformation and leukemogenesis. 46

Gabet et al. ${ }^{51}$ studied the HTLV-I replication over 2 years in a patient with IDH associated with strongyloidiasis, a parasitosis which predisposes carriers of the virus to develop ATL. ${ }^{75}$ They observed elevated viral loads, together with persistent oligoclonal expansion of infected lymphocytes. The replication pattern was very different from that observed in asymptomatic carriers, being more similar to the pattern found in ATL. 51

In animal experiments, inoculation of HTLV-I via the oral route induces host HTLV-I-specific T-cell unresponsiveness and results in increased viral load. Since there are similarities between experimental oral inoculation and infection by breast-feeding, these findings

Table 1 - Cases of ATL in childhood and adolescence ${ }^{76}$

\begin{tabular}{|c|c|c|c|c|c|c|c|c|}
\hline No. & Authors & $\begin{array}{c}\text { Age/ } \\
\text { sex }\end{array}$ & Skin & $\mathbf{L N}$ & $\begin{array}{c}\text { Spleen } \\
\text { and/or liver }\end{array}$ & BM & CNS & $\begin{array}{l}\text { Survival } \\
\text { (years) }\end{array}$ \\
\hline 1 & Vilmer et al. 77 & $1 / M$ & + & - & - & - & - & Alive (8) \\
\hline 2 & Foucar et al. ${ }^{78}$ & $16 / F$ & + & + & + & + & - & Death $(0.1)$ \\
\hline 3 & Ikaí et al. 79 & $10 / F$ & + & - & - & - & - & Alive (3.6) \\
\hline 4 & Ratner et al. ${ }^{80}$ & $7 / F$ & + & $\ldots$ & $\ldots$ & $\ldots$ & $\ldots$ & Death $(\ldots)$ \\
\hline 5 & Fort et al. ${ }^{81}$ & $16 / M$ & - & + & + & - & - & Death $(0.2)$ \\
\hline 6 & Blank et al. 82 & $17 / \mathrm{M}$ & - & + & + & $\ldots$ & $\ldots$ & Death $(\ldots)$ \\
\hline 7 & Williams et al. 83 & $12 / \mathrm{M}$ & - & $\ldots$ & + & + & - & $\ldots$ \\
\hline 8 & Wilks et al. 84 & $16 / F$ & + & + & + & + & - & Death $(0.3)$ \\
\hline 9 & Broniscer et al. ${ }^{85}$ & $16 / F$ & + & + & + & + & + & Alive $(\ldots)$ \\
\hline 10 & Lin et al. ${ }^{86}$ & $12 / \mathrm{F}$ & + & + & - & + & - & Alive (5) \\
\hline 11 & Valle et al. 87 & $15 / M$ & + & + & + & $\ldots$ & $\ldots$ & Death (0.2) \\
\hline 12 & Lewis et al. ${ }^{88}$ & $13 / \mathrm{M}$ & + & - & - & - & - & Alive $(\ldots)$ \\
\hline 13 & Bittencourt et al. 89 & $18 / \mathrm{F}$ & + & + & - & + & - & Death (1.9) \\
\hline 14 & Bittencourt et al. (personal communication)* & $9 / M$ & + & - & - & - & - & Alive (14) \\
\hline 15 & Pombo de Oliveira et al. ${ }^{90+}$ & $2 / F$ & + & + & + & $\ldots$ & + & Death (2) \\
\hline 16 & Pombo de Oliveira et al. $90 *$ & $18 / \mathrm{M}$ & + & + & + & $\cdots$ & + & Death $(0.6)$ \\
\hline 17 & Pombo de Oliveira et al. $90 *$ & $11 / \mathrm{M}$ & + & + & + & $\ldots$ & + & Death (4) \\
\hline 18 & Pombo de Oliveira et al. $90 *$ & $15 / M$ & + & + & - & $\ldots$ & + & Death $(0.2)$ \\
\hline 19 & Pombo de Oliveira et al. $90 *$ & $14 / M$ & + & + & + & $\ldots$ & - & Death $(0.5)$ \\
\hline 20 & Pombo de Oliveira et al. ${ }^{90 *}$ & $16 / \mathrm{F}$ & - & + & + & $\ldots$ & - & Death $(0.2)$ \\
\hline 21 & Pombo de Oliveira et al. $90 *$ & $16 / F$ & - & + & + & $\ldots$ & - & Death $(0.2)$ \\
\hline 22 & Pombo de Oliveira et al. $90 *$ & $7 / M$ & - & + & - & $\ldots$ & - & Alive (3) \\
\hline 23 & Mahé et al. 31 & $17 / F$ & + & + & - & $\ldots$ & - & Death $(0.16)$ \\
\hline 24 & Oliveira et al. 91 & $16 / F$ & + & - & - & - & - & Alive (1.4) \\
\hline
\end{tabular}

$\mathrm{ATL}=$ adult T-cell leukemia/lymphoma; $\mathrm{BM}=$ bone marrow $; \mathrm{CNS}=$ central nervous system; $\mathrm{LN}=$ lymph nodes, ... = not reported .

* Monoclonal viral integration.

$\dagger$ Bone marrow involved in four cases. 
strongly suggest that the known epidemiological risk factors for ATL (vertical transmission and high viral load) are linked by an insufficient specific T-cell response. This risk might be reduced if the carrier recovers the specific immune response. 95 Thus, there would be an elevated risk for development of ATL in a small group of vertically infected carriers with a persistently low immune response to the virus, despite the presence of an elevated viral load. It is probable that the magnitude of the host immune response at primary infection might be a crucial determinant of persistent HTLV-I levels. ${ }^{95}$

It is possible that the development of ATL during childhood or adolescence could be related to acquisition of the infection very early, by intrauterine transmission, in the birth canal or via breastfeeding in the first months of life, considering that the immune system of the fetus and child during the first few months of life is much less efficient.

\section{Treatment}

It is very important that ATL cases are recognized, since both prognosis and treatment are different from the other types of leukemia/lymphoma. ATL does not respond to chemotherapy as do other lymphomas and leukemias and, within a variety of treatment protocols that are being tried out, the most widest used is interferon-alpha in association with zidovudine. ${ }^{96}$ It is important to emphasize that therapeutic management also depends on the clinical form of ATL. 96,97

\section{Ocular manifestations}

Opacity and ulcer of the cornea have been described in IDH patients. 27,36

HTLV-I-associated uveitis is a disease of middle-aged adults which can occur in HTLV-I carriers, or in patients with HAM/TSP. ${ }^{98}$ Notwithstanding, there are five reported cases of HTLV-I-associated uveitis in children aged from 3 to 14 years; four of them were female, and with symptomatology similar to that observed in adults. ${ }^{99,100}$ This pathology responds well to topical or systemic treatment with corticosteroids but may present relapses. 100

More recently, Nakao \& Ohba ${ }^{101}$ described a case of vasculitis of the retina accompanied by mild visual abnormalities in three adolescents with HTLV-I, stating that the lesions of these cases differed from vascular abnormalities commonly seen in HTLV-I-associated uveitis. Progression is slow, response to corticosteroids is poor and the final result is diffuse chorioretinal degeneration.

\section{Conclusions}

As has been stated, IDH, ATL and the juvenile forms of HAM/TSP occur in individuals who have been infected vertically, and it is known that the main route of vertical transmission is breastfeeding. This demonstrates the importance of preventing this form of transmission in endemic areas, such as Salvador, which should be based on serological screening of pregnant women, and counseling the seropositive mothers to avoid breastfeeding. 4 Considering that the mothers infected with HTLV-I in our country are generally from lower social classes, it is necessary that alternative nutritional sources and pediatric care be provided for their children. In Nagasaki (Japan), a wide ranging intervention employing this strategy blocked around $80 \%$ of vertical HTLV-I transmission. ${ }^{14}$

Vertical HTLV-I transmission poses a serious public health problem and merits more extensive investigation so that its significance in other Brazilian cities can be evaluated.

\section{References}

1. Barbosa HS, Bittencourt AL, Barreto de Araujo I, Pereira Filho CS, Furlan R, Pedrosa C, et al. Adult T-cell leukemia/lymphoma in northeastern Brazil: a clinical, histopathologic, and molecular study. J Acquir Immune Defic Syndr. 1999;21:65-71.

2. Bittencourt AL. Vertical transmission of HTLV-I/II: a review. Rev Inst Med Trop Sao Paulo. 1998;40:245-51.

3. Soares BCC, Castro MSM, Proietti FA. Epidemiologia do HTLV-I/ II. In: Proietti AB, editor. HTLV-I/II. Cadernos hemominas. Belo Horizonte: Fundação Centro de Hematologia e Hemoterapia de Minas Gerais; 2000. p. 53-75. Vol. XI

4. Galvão-Castro B, Loures L, Rodrigues LG, Sereno A, Ferreira Junior OC, Franco LG, et al. Distribution of human T-Iymphotropic virus type I among blood donors: a nationwide Brazilian study. Transfusion. 1997;37:242-3.

5. Dourado I, Alcantara LC, Barreto ML, da Gloria Teixeira M, Galvão-Castro B. HTLV-I in the general population of Salvador, Brazil: a city with African ethnic and sociodemographic characteristics. J Acquir Immune Defic Syndr. 2003;34:527-31.

6. Bittencourt $A L$, Dourado $I$, Filho $P B$, Santos $M$, Valadão $E$ Alcantara LC, et al. Human T-Cell Iymphotropic virus type 1 infection among pregnant women in Northeastern Brazil. J Acquir Immune Defic Syndr. 2001;26:490-4.

7. Kinoshita K, Hino S, Amagaski T, Ikeda S, Yamada Y, Suzuyama $\mathrm{J}$, et al. Demonstration of adult $\mathrm{T}$ cell leukemia virus antigen in milk from three sero-positive mothers. Gann. 1984;75:103-5.

8. Tsuji $Y$, Doi H, Yamabe T, Ishimaru T, Miyamoto T, Hino S. Prevention of mother to child transmission of human $\mathrm{T}$ lymphotropic virus type-I. Pediatrics. 1990;86:11-7.

9. Yamanouchi K, Kinoshita K, Moriuchi R, Katamine S, Amagasaki $\mathrm{T}$, Ikeda $\mathrm{S}$, et al. Oral transmission of human T-cell leukemia virus type-I into a common marmoset (Callithrix jacchus) as an experimental model for milk-borne transmission. Jpn J Cancer Res. $1985 ; 76: 481-7$

10. Ando Y, Saito K, Nakano S, Kakimoto K, Furuki K, Tanigawa T, et al. Bottle-feeding can prevent transmission of HTLV-I from mothers to their babies. J Infect. 1989;19:25-9.

11. Takahashi K, Takezaki T, Oki T, Kawakami K, Yashiki S, Fujiyoshi $\mathrm{T}$, et al. Inhibitory effect of maternal antibody on mother-tochild transmission of human T-lymphotropic virus type I. The Mother-to-Child Transmission Study Group. Int J Cancer. 1991;49:673-7.

12. Hirata M, Hayashi J, Noguchi A, Nakashima K, Kajiyama W, Kashiwagi S, et al. The effects of breastfeeding and presence of antibody to p40tax protein of human T cell lymphotropic virus type-I on mother-to-child transmission. Int J Epidemiol. 1992; 21:989-94.

13. Oki T, Yoshinaga M, Otsuka H, Miyata K, Sonoda S, Nagata Y. A sero-epidemiological study on mother-to-child transmission of HTLV-I in Southern Kyushu, Japan. Asia Oceania J Obstet Gynaecol. 1992;18:371-7. 
14. Hino S, Katamine S, Miyata $\mathrm{H}$, Tsuji $\mathrm{Y}$, Yamabe $\mathrm{T}$, Miyamoto $\mathrm{T}$. Primary prevention of HTLV-I in Japan. J Acquir Immune Defic Syndr Hum Retrovirol. 1996;13 Suppl 1:S199-203.

15. Ureta-Vidal A, Angelin-Duclos C, Tortevoye $P$, Murphy E, Lepere JF, Buigues RP, et al. Mother-to-child transmission of human Tcell-leukemia/lymphoma virus type I: implication of high antiviral antibody titer and high proviral load in carrier mothers. Int J Cancer. 1999;82:832-6.

16. Bittencourt AL, Sabino EC, Costa MC, Pedroso C, Moreira L. No evidence of vertical transmission of HTLV-I in bottle-fed children. Rev Inst Med Trop Sao Paulo. 2002;44:63-5.

17. Ijichi $S$, Nakagawa M, Umehara F, Higuchi I, Arimura K, Izumo $\mathrm{S}$, et al. HAM/TSP: recent perspectives in Japan. J Acquir Immune Defic Syndr Hum Retrovirol. 1996;13 Suppl 1:S26-32.

18. Carvalho EM, Bacellar O, Porto AF, Braga S, Galvao-Castro B, Neva F. Cytokine profile and immunomodulation in asymptomatic human T-lymphotropic virus type 1-infected blood donors. J Acquir Immune Defic Syndr. 2001;27:1-6.

19. Santos $S B$, Porto $A F$, Muniz AL, de Jesus AR, Magalhães $E$, Melo $A$, et al. Exacerbated inflammatory cellular immune response characteristics of HAM/TSP is observed in a large proportion of HTLV-I asymptomatic carriers. BMC Infect Dis. 2004;4:7.

20. Brites C, Weyll M, Pedroso C, Badaro R. Severe and Norwegian scabies are strongly associated with retroviral (HIV-1/HTLV-1) infection in Bahia, Brazil. AIDS. 2002;16:1292-3.

21. Gonçalves DU, Guedes AC, Proietti AB, Martins ML, , Lambertucci $J R$, et al. Dermatologic lesions in asymptomatic blood donors seropositive for human T cell lymphotropic virus type-1. Am J Trop Med Hyg. 2003;68:562-5.

22. Marsh BJ. Infectious Complications of human $\mathrm{T}$ cell leukemia/ lymphoma virus type I infection. Clin Infect Dis. 1996;23:138-45.

23. Marinho J, Galvão-Castro B, Rodrigues LC, Barreto ML. Increased risk of tuberculosis with human T-Iymphotropic virus-1 infection: a case-control study. J Acquir Immune Defic Syndr. 2005;40: 625-8.

24. Sweet RD. A pattern of eczema in Jamaica. B J Dermatol. 1966; 78:93-100.

25. LaGrenade L, Hanchard B, Fletcher V, Cranston B, Blattner W. Infective dermatitis of Jamaican children: a marker for HTLV-I infection. Lancet. 1990;336:1345-7.

26. Gonçalves DU, Guedes AC, Carneiro-Proietti AB, Lambertucci JR. HTLV-I associated infective dermatitis may be an indolent HTLV-I associated lymphoma. Braz J Infect Dis. 2000;4:100-2.

27. Oliveira Mde F, Brites $C$, Ferraz N, Magalhães $P$, Almeida $F$, Bittencourt AL. Infective dermatitis associated with the human T-cell lymphotropic virus type I HTLV-I in Salvador, Bahia, Brazil. Clin Infect Dis. 2005;40:e90-6.

28. La Grenade L, Manns A, Fletcher V, Derm D, Carberry C, Hanchard B, et al. Clinical, pathologic, and immunologic features of human T-lymphotrophic virus type I-associated infective dermatitis in children. Arch Dermatol. 1998;134:439-44.

29. Suite M, Jack N, Basdeo-Maharaj K, Edwards J, White F, Blattner $W$, et al. Infective dermatitis in Trinidad and Tobago. Aids Res Hum Retroviruses. 1994;10:447.

30. Aquije M, Ballona R. Dermatitis infectiva asociada a HTLV-I en el Servicio de Dermatología del instituto de la Salud del Niño. Folia Dermatol Peruana. 2002;13:1-8.

31. Mahé A, Meertens L, Ly F, Sow PS, Diop CT, Samb ND, et al. Human T-cell leukaemia/lymphoma virus type 1-associated infective dermatitis in Africa: a report of five cases from Senegal. Br J Dermatol. 2004;150:958-65.

32. Tsukasaki K, Yamada Y, Ikeda S, Tomonaga M. Infective dermatitis among patients with ATL in Japan. Int J Cancer. 1994; 57:293.

33. La Grenade L, Schwartz RA, Janniger CK. Childhood dermatitis in the tropics: with special emphasis on infective dermatitis, a marker for infection with human T-cell leukemia virus-I. Cutis. 1996;58:115-8.

34. Murphy EL, Figueroa JP, Gibbs WN, Holding-Cobham M, Cranston B, Malley $\mathrm{K}$, et al. Human T-lymphotropic virus type I (HTLV-I) seroprevalence in Jamaica. I. Demographic determinants. Am J Epidemiol. 1991;133:1114-24.

35. Maloney EM, Hisada M, Palmer P, Brooks K, Pate E, Wiktor SZ, et al. Human T cell lymphotropic virus type I-associated infective dermatitis in Jamaica: A case report of clinical and biologic correlates. Pediatr Infect Dis J. 2000;19:560-5.

36. La Grenade L. HTLV-I-associated infective dermatitis: past, present and future. J Acquir Immune Defic Syndr Hum Retrovirol. 1996;13 Suppl 1:S46-9.

37. Rueda R, Blank A. HTLV-I associated cutaneous manifestations. In: Zanonovic V, editor. HTLV -Truths and Questions. Cali: Feriva; 1996. p. 212-22.
38. Bittencourt AL, Oliveira Mde F, Brites $C$, Van Weyenbergh JV, da Silva Vieira MG, Araújo I. Histopathological and immunohistochemical studies of infective dermatitis associated with HTLV-I. Eur J Dermatol. 2005;15:26-30.

39. Holden CA, Parish WE. Atopic dermatitis. In: Champion $\mathrm{RH}$, Bourton JL, Burns DA, Breathnach SM, editors. Rook/Wilkinson/ Ebling Textbook of Dermatology. 6th ed. London: Blackwell Scientific Publications; 1998. p. 681-708.

40. Hurwitz S. Clinical Pediatric Dermatology: a textbook of skin disorders of childhood and adolescence. 2nd ed. Philadelphia: WB Saunders; 1993.

41. Maloney EM, Nagai M, Hisada M, Soldan SS, Goebel PB, Carrington $M$, et al. Prediagnostic human $T$ lymphotropic virus type I provirus loads were highest in Jamaican children who developed seborrheic dermatitits and severe anemia. J Infect Dis. 2004; 189:41-5.

42. Burton JL, Holden CA. Eczema, lichenification and prurigo. In: Champion RH, Bourton JL, Burns DA, Breathnach SM, editors. Rook/Wilkinson/Ebling Textbook of Dermatology. 6th ed. London: Blackwell Scientific Publications; 1998. p. 629-80.

43. Zaidi Z, Wahid Z, Cochinwala R, Soomro M, Qureishi A. Correlation of the density of yeast Malassezia with the clinical severity of seborrhoeic dermatitis. J Pak Med Assoc. 2002;52:504-6.

44. LaGrenade L, Sonoda S, Miller W, Pate E, Rodgers-Johnson P, Hanchard B, et al. HLA DRB1* DQB1* haplotype in HTLV-Iassociated familial infective dermatitis may predict development of HTLV-I associated myelopathy/tropical spastic paraparesis. Am J Med Genet. 1996;61:37-41.

45. Shinzato O, Kamihira S, Ikeda S, Kondo H, Kanda T, Nagata Y, et al. Relationship between the anti-HTLV-1 antibody level, the number of abnormal lymphocytes and the viral-genome dose in HTLV-1-infected individuals. Int J Cancer. 1993;54:208-12.

46. Tschachler $E$, Franchini G. Infective dermatitis a pabulum for human T-lymphotrophic virus type I leukemogenesis? Arch Dermatol. 1998;134:487-8

47. Primo JR, Brites C, Oliveira M de F, Moreno-Carvalho O, Machado $M$, Bittencourt $A L$. Infective dermatitis and juvenile HTLV-I-associated myelopathy/tropical spastic paraparesis (HAM/TSP). Clin Infect Dis. 2005;41:535-41.

48. Hanchard B, LaGrenade L, Carberry C, Fletcher V, Williams E, Cranston $B$, et al. Childhood infective dermatitis evolving into adult T-cell leukaemia after 17 years. Lancet. 1991;338:1593-4.

49. LaGrenade L, Morgan C, Carberry C, Hanchard B, Fletcher V, Gray R, et al. Tropical spastic paraparesis occurring in HTLV-1 associated infective dermatitis. Report of two cases. West Indian Med J. 1995;44:34-5.

50. Bittencourt AL. Adult T-cell leukemia/lymphoma (ATL) in Bahia, Brazil. Braz J Infect Dis. 2005;9:437-8.

51. Gabet AS, Kazanji M, Couppie P, Clity E, Pouliquen JF, SainteMarie D, et al. Adult T-cell leukemia/lymphoma-like human Tcell leukemia virus-1 replication in infective dermatitis. $\mathrm{Br}$ J Haematol. 2003;123:406-12.

52. Moreno-Carvalho OA, Santos JI, Di Credico G, Galvao-Castro B. Evidence of preferential female prevalence of HTLV-I associated tropical spastic paraparesis in Bahia-Brazil. Arq Neuropsiquiatr. 1992; 50:183-8.

53. Nakagawa M, Izumo S, Ijichi S, Kubota H, Arimura K, Kawabata $M$, et al. HTLV-I associated myelopathy: analysis of 213 patients based on clinical features and laboratory findings. J Neurovirol. 1995; 1:50-61.

54. McKhann G 2nd, Gibbs CJ Jr., Mora CA, Rodgers-Johnson PE, Liberski PP, Gdula WJ, et al. Isolation and characterization of HTLV-1 from symptomatic family members with tropical spastic paraparesis (HTLV-1 encephalomyeloneuropathy). J Infect Dis. 1989; 160:371-9.

55. Kramer A, Maloney EM, Morgan OS, Rodgers-Johnson P, Manns A, Murphy EL, et al. Risk factors and cofactors for human T-cell lymphotropic virus type I (HTLV-I)-associated myelopathy/ tropical spastic paraparesis (HAM/TSP) in Jamaica. Am J Epidemiol. 1995;142:1212-20.

56. Kayembe K, Goubau P, Desmyter J, Vlietinck R, Carton H. A cluster of HTLV-1 associated tropical spastic paraparesis in Equateur (Zaire): ethnic and familial distribution. J Neurol Neurosurg Psychiatry. 1990;53:4-10.

57. Osame M, Igata A, Usuku K, Rosales RL, Matsumoto M. Motherto-child transmission in HTLV-I-associated myelopathy. Lancet. 1987; $1: 106$.

58. Araújo AP, Fontenelle LM, Pádua PA, Maia Filho $H$, Araújo AQ. Juvenile human $T$ Iymphotropic virus type I-associated myelopathy. Clin Infect Dis. 2002;35:201-4.

59. Muniz AL, Rodrigues W Jr., Jesus AR, Braga S, Porto A, Bacellar $A$, et al. Juvenile HAM/TSP of subacute evolution: case report and literature Review. Cienc Saude. 2002;2:59-65. 
60. Quintas S, Moreno T, Lobo-Antunes N, Levy-Gomes A. Tropical spastic paraparesis and HTLV-I associated myelopathy in infancy. A case report and review of the literature. Rev Neurol. 2004;39:1133-6.

61. de Oliveira Mde F, Bittencourt AL, Brites C, Soares G, Hermes C, Almeida FO. HTLV-I associated myelopathy/tropical spastic paraparesis in a 7-year-old boy associated with infective dermatitis. J Neurol Sci. 2004;222:35-8.

62. Hanchard B. Outcomes of early life exposure to human T cell lymphotropic virus type 1 . Clin Infect Dis. 2005;41:542-3.

63. Primo JR. Mielopatia associada ao HTLV-I/paraparesia tropical espástica(HAM/TSP) em pacientes com dermatite infecciosa na faixa etária infanto-juvenil [tese]. Salvador (BA): Universidade Federal da Bahia; 2005.

64. Leite AC, Silva MT, Alamy AH, Afonso CR, Lima MA, AndradaSerpa MJ, et al. Peripheral neuropathy in HTLV-I infected individuals without tropical spastic paraparesis / HTLV-Iassociated myelopathy. J Neurol. 2004;251:877-81.

65. Imamura A, Kitagawa T, Ohi Y, Osame M. Clinical manifestation of human T-cell lymphotropic virus type-I-associated myelopathy and vesicopathy. Urol Int. 1991;46:149-53.

66. Saito M, Kondo A, Kato K, Gotoh M. Bladder dysfunction due to human $\mathrm{T}$ - Iymphotrophic virus type I associated myelopathy. $\mathrm{Br}$ J Urol. 1991;68:365-8.

67. Correia J, Primo J, Barroso U, Oliveira MF, Brites C, Bittencourt AL. Bladder dysfunction in juvenil HTLV-I-associated myelopathy/ tropical spastic paraparesis (HAM/TSP) and infective dermatitis: a report on three cases. AIDS Res Hum Retroviruses. 2005;21:461-515.

68. Yoshida $Y$, Sakamoto $Y$, Yoshimine A, Maruyama $Y$, Ikegami N, Inose $M$, et al. Three cases of juvenile onset HTLV-I-associated myelopathy with pseudohypoparathyroidism. J Neurol Sci. 1993; 118:145-9.

69. Machigashira N, Yoshida Y, Wang S, Osame M. HTLV-1-associated myelopathy/tropical spastic paraparesis with pseudohypoparathyroidism. Neurology. 2001;56:104-6.

70. Usuku K, Sonoda S, Osame M, Yashiki S, Takahashi K, Matsumoto $M$, et al. HLA haplotype-linked high immune responsiveness against HTLV-I in HTLV-I-associated myelopathy: comparison with adult T-cell leukemia/lymphoma. Ann Neurol. 1988;23 Suppl:S143-50.

71. Mueller NE, Blattner WA. Retroviruses: HTLV-I. In: Evans AS, Kaslow R, editors. Viral infections of humans: epidemiology and control. New York: Plenum Medical Press; 1997. p. 785-813.

72. Jeffery KJ, Usuku K, Hall SE, Matsumoto W, Taylor GP, Procter $\mathrm{J}$, et al. HLA alleles determine human T-lymphotropic vírus-I (HTLV-I) proviral load and the risk of HTLV-I-associated myelopathy. Proc Natl Acad Sci U S A. 1999;96:3848-53.

73. Jainulabdeen J, Ifthikharuddin, Rosenblatt JD. HTLV types I and II. In: Mandell GL, Bennet Je, Dolin R. Mandell, Douglas, and Bennett's principles and practice of infectious diseases. 5th ed. London: Churchill Livingstone; 2000. p. 1862-73.

74. Pombo de Oliveira MS, Loureiro P, Bittencourt A, Chiattone C, Borducchi D, De Carvalho SM, et al. Geographic diversity of adult T-cell leukemia lymphoma in Brazil. The Brazilian ATLL Study Group. Int J Cancer. 1999;83:291-8.

75. Gabet AS, Mortreux F, Talarmin A, Plumelle Y, Leclercq I, Leroy $A$, et al. High circulating proviral load with oligoclonal expansion of HTLV-I bearing T cells in HTLV-1 carriers with strongyloidiasis. Oncogene. 2000;19:4954-60.

76. Bittencourt AL, Primo JL, Oliveira FP. Manifestações infantojuvenís associadas a infecção pelo virus linfotrópico de células $T$ humanas (HTLV-I). In: Proietti AB, editor. Cadernos Hemominas. HTLV-I. Belo Horizonte: Fundação Centro de Hematologia e Hemoterapia de Minas Gerais; 2006. p. 174-91.

77. Vilmer E, Le Deist F, Fischer A, Griscelli C, Nezelof C, de Prost $Y$, et al. Smouldering $T$ Iymphoma related to HTLV-I in a Sicilian child. Lancet. 1985;2:1301.

78. Foucar K, Carroll TJ Jr., Tannous R, Peterson L, Goeken JA, Binion $S$, et al. Nonendemic adult T-cell leukemia/lymphoma in the United States: report of two cases and review of the literature. Am J Clin Pathol. 1985;83:18-26.

79. Ikai K, Uchiyama T, Maeda M, Takigawa M. Sezary-like syndrome in a 10-year-old girl with serologic evidence of human T-cell Iymphotropic virus type I infection. Arch Dermatol. 1987;123: 1351-5.

80. Ratner L, Poiesz BJ. Leukemias associated with human T-cell lymphotropic virus type $\mathrm{I}$ in a non-endemic region. Medicine (Baltimore). 1988;67:401-22.

81. Fort JA, Graham-Pole J, Mottshaw G. Adult-type T-cell lymphoma in an adolescent with human T-Iymphotropic virus type I seropositivity. Med Pediatr Oncol. 1989;17:236-8.
82. Blank A, Yamaguchi K, Blank M, Zaninovic V, Sonoda S, Takatsuki K. Six Colombian patients with adult T-cell leukemia / lymphoma. Leuk Lymphoma. 1993;9:407-12.

83. Williams CK, Alexander SS, Bodner A, Levine A, Saxinger C, Gallo RC, et al. Frequency of adult T-cell leukaemia / lymphoma and HTLV-I in Ibadan Nigéria. Br J Cancer. 1993;67:783-6.

84. Wilks RJ, LaGrenade L, Hanchard B, Campbell M, Murphy J, Cranston B, et al. Sibling adult T-cell leukemia/lymphoma and clustering of human T-cell lymphotropic virus type I infection in a Jamaican family. Cancer. 1993;72:2700-4.

85. Broniscer A, Ribeiro RC, Srinivas RV, Behm FG, Head DR, Raimondi SC, et al. An adolescent with HTLV-I associated adult $\mathrm{T}$ cell leukemia treated with interferon alfa and zidovudine. Leukemia. 1996;10:1244-8.

86. Lin BT, Musset M, Szekely AM, Alexandre J, Fraitag S, Bodemer $C$, et al. Human T-cell lymphotropic virus-1-positive T-cell leukemia/lymphoma in a child. Report of a case and review of the literature. Arch Pathol Lab Med. 1997;121:1282-6.

87. do Valle AC, Galhardo MC, Leite AC, Araújo AQ, Cuzzi-Maya T, Maceira JP, et al. Adult T-cell leukaemia/lymphoma associated with HTLV-I infection in a Brazilian adolescent: case report. Rev Inst Med Trop Sao Paulo. 2001;43:283-6.

88. Lewis JM, Vasef MA, Seabury Stone M. HTLV-I-associated granulomatous T-cell lymphoma in a child. J Am Acad Dermatol. 2001;44:525-9.

89. Bittencourt A, Brites C, Pereira Filho C, Dias NF, Vieira M. Linfoma/leucemia de células T associado ao HTLV-I (ATL) em criança e adolescente. An Bras Dermatol. 2001;76 Supl 2:88.

90. Pombo-de-Oliveira MS, Dobbin JA, Loureiro P, Borducchi D, Maia RC, Fernandes MA, et al. Genetic mutation and early onset of $\mathrm{T}$ Cell leukemia in pediatric patients infected at birth with HTLV-I. Leuk Res. 2002;26:155-61.

91. de Oliveira MF, Primo JRL, Rebouças ATS, Ferraz N, Bittencourt $A L$. Forma inicial de linfoma em adolescente com mielopatia e dermatite infecciosa associadas ao HTLV-I. An Bras Dermatol. 2005;80:S241-2.

92. Shimoyama M. Diagnostic criteria and classification of clinical subtypes of adult T-cell leukaemia-lymphoma. A report from the Lymphoma Study Group (1984-87). Br J Haematol. $1991 ; 79: 428-37$.

93. Bittencourt AL, Barbosa HS, Carvalho BAC, Ferraz N, Brites C. Linfomas primários da pele associados ao HTLV-I na Bahia. Achados clínico-patológicos e imuno-istoquímicos. An Bras Dermatol. 2005;80:S246-7.

94. Cordoliani F, Gessain A, Vignon-Pennamen MD, Mouly F, Moulonguet, Flageul B, et al. Adult T-cell lymphoma associated with HTLV-I: a familial form. Ann Dermatol Venereol. 1998;125: 708-10.

95. Kannagi M, Ohashi T, Harashima N, Hanabuchi S, Hasegawa A. Immunological risks of adult T-cell leukemia at primary HTLVI infection. Trends Microbiol. 2004;12:346-52.

96. Hermine O, Allard I, Levy V, Arnulf B, Gessain A, Bazarbachi A; French ATL therapy group. A prospective phase II clinical trial with the use of zidovudine and interferon-alpha in the acute and lymphoma forms of adult T-cell leukemia/lymphoma. Hematol J. 2002;3:276-82.

97. Bazarbachi A, Ghez D, Lepelletier Y, Nasr R, de The H, ElSabban ME, et al. New therapeutic approaches for adult T-cell leukaemia. Lancet Oncol. 2004;5:664-72.

98. Ohba N, Nakao K, Isashiki $Y$, Kaminagayoshi T, Sonoda S, Yashiki S, et al. Clinical features of HTLV-I associated uveitis determined in multicenter collaborative study. Study Group for HTLV-I Associated Ocular Diseases. Jpn J Ophthalmol. 1994;38:168-74.

99. Katakura S, Iijima Y, Imagawa T, Tokuhiro E, Nakamura S, Yabuki $\mathrm{K}$, et al. Human $\mathrm{T}$ cell lymphotropic virus type I associated uveitis in a child. Br J Ophthalmol. 1997;81:1016.

100. Kihara K, Tsuruda M, Ono A, Ikeda E, Hikita N, Miyata N, et al. Human T-lymphotropic virus type 1 uveitis in children. Nippon Ganka Gakkai Zasshi. 1997;101:538-3.

101. Nakao K, Ohba N. Human T-cell lymphotropic virus type 1associated retinal vasculitis in children. Retina. 2003;23: 197-201.

Correspondence:

Achiléa Bittencourt

Hospital Universitário Professor Edgard Santos - UFBA

Serviço de Anatomia Patológica

Rua Dr. Augusto Viana, s/no

CEP 40110-060 - Salvador, BA -Brazil

E-mail: achilea@uol.com.br 